\title{
Strategies to Improve the Sustainability in Promoting Transparency, Accountability and Anti-Corruption: An Imaginary Dialogue
}

\author{
Eko Ganis Sukoharsono \\ Professor of Sustainability Accounting \\ University of Brawijaya
}

\begin{abstract}
The paper is an imaginary dialogue. The dialogue is between two professionals: SDGist and Auditor. To bring up their imagination, postmodernism is used to explore the dialogue. Both are trying to discuss the current issues on SDGs. The objective of the paper is to explicate strategies to improve SDGs in promoting transparency, accountability and anti-corruption, which is in particular to promote peaceful and inclusive societies for sustainable development, provide access to justice for all and build effective, accountable and inclusive institutions at all levels, especially on the Goal 16.4 to 16.6 .

The result of the dialogue, there are 9 strategies to improve the SDGs in promoting transparency, accountability and anti-corruption. They are the ICSP on SDGs Implementation: Socializing the Sustainability Reporting, implementing of e-government, promoting more investment, fitting policies nationally and internationally relevant to the goal 16.4 to 16.6 , supporting inclusive growth and well being, ensuring the 5Ps' sustainability, promoting partnerships, strengthening data availability and capacity, and facilitating follow up and review.
\end{abstract}

\section{Prologue: Introducing Two Professionals, SDGist and Auditor, on SDGs}

I wrote this paper as a response to the Audit Board Organising Committee, the Republic of Indonesia's invitation asking me to be a panelist at the ASEAN-SAI Seminar, 2 April 2018 on the main theme of Increasing the awareness of SDGs: Promoting Transparency, Accountability and Anti-Corruption. I received the invitation by coincidently via Mr. Andrew Twohig, my colleague at the Institute of Certified Sustainability Practitioners (ICSP). It was on Thursday, 30 March 2018. With no objection, I said 'yes', I will prepare with some issues which may be relevant to the Seminar. Finally, on Friday night, some clear understandings were given by the $\mathrm{OC}$ to me concerning the main issues that I could address during the session.

It is an honour for me to be one of the panelists of the Seminar. I believe it would be good to share a thought on the sustainable development issues. Even though, it is not easy for me to prepare with such hectic atmospher of the end of the March 2018, I committed to prepare as best I could with a short preparation.

The paper is originally presented at the ASEAN SAI SEMINAR on Increasing the Awareness of Sustainable Development Goals: Promoting Transparency, Accountability and Anti-Corruption, BPK (the Audit Board, the Republic of Indonesia), Jakarta, 2 April 2018 
Sustainable development has become a 'world icon' at least from 2015 to 2030. It was started from the idea of 25 September 2015, when the world leaders meeting in New York adopted United Nations Resolution A/RES/70/1, 'Transforming our world: The 2030 Agenda for Sustainable Development.' As the 1st sentence at the Preamble, the Agenda is "a plan of action for people, planet and prosperity", and "also seeks to strengthen universal peace in larger freedom."

With the main theme of the Seminar, the purpose of the paper is to explicate strategies to improve the sustainable development goals (SDGs) in promoting transparency, accountability and anti-corruption. To explicate the paper, I use a framework of an imaginary dialogue using the prespective of Postmodernism. The imaginary dialogue is between two persons: with naming SDGist and Auditor. Both are members of Supreme Audit Institution. SDGist is a lady who has well knowledge on SDGs, whereas Auditor is a gentleman who has a competency on financial and non-financial audits.

Both are focusing on the discussions of SDGS with primary goal target on Goal 16 which is Promote peaceful and inclusive societies for sustainable development, provide access to justice for all and build effective, accountable and inclusive institutions at all levels. In particulars, it focuses on Goal 16.4 to 16.6.

Auditor $\quad$ : Lady, SDGist, are SDGs ambitious?

SDGist : Auditor ... too early you are asking me with the question.

SDGist : (She continually and immediately answer it) Basically, yes ... it is very ambitious goals. Not only ambitious, but it also very broad context. Please, Auditor, you may imagine, as pointed out by OECD, all countries, whether high, middle or even low income countries, should make fantastic improvement of the 17 goals by 2030.

Auditor $\quad$ : Lha ... rak angel tenan tho (It is difficult).

Auditor : (He then says ...) Lho ... opo'o kog 17 goals (why is that of 17 goals), SDGist?

Historically, the untargeted result (if it is not to say a failure) of Millinium Development Goals (MDGs) made an idea to further step for another 15 years to go as defined as SDGs. The vast majority of developing countries has missed most of the MDG targets of 2015, including Indonesia. Nearly all African countries missed most of them. SDGs emerged with optimism where 17 goals are set to be accomplished by the end of 2030 with 169 indicators (ICSU, 2015).

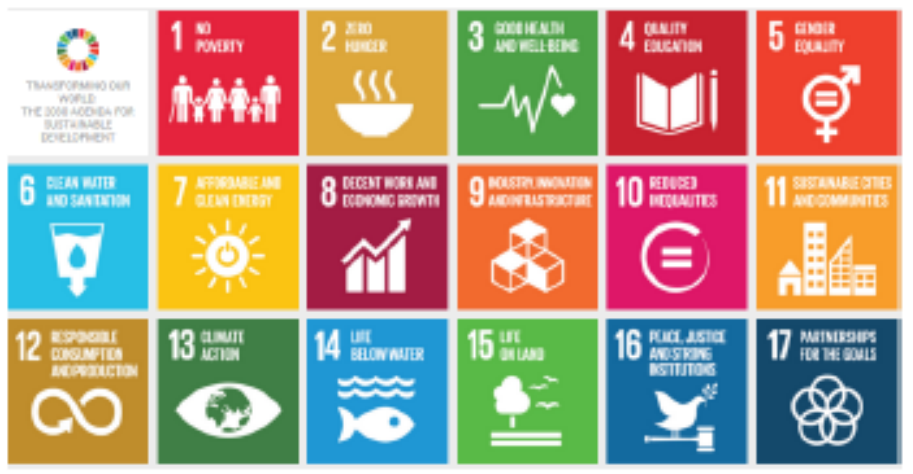


SDGist : Auditor ... please look at the original ideas here that the Goals and targets stimulate countries' action over the next 15 years in areas of critical importance for humanity and the planet.

See Auditor here is an idea for our People

SDGs determined targeting to end poverty and hunger, in all their forms and dimensions, and to ensure that all human beings can fulfil their potential in dignity and equality and in a healthy environment.

See Auditor, here is an ide for our Planet

SDGs determined targeting to protect the planet from degradation, including through sustainable consumption and production, sustainably managing its natural resources and taking urgent action on climate change, so that it can support the needs of the present and future generations.

See Auditor here is an ide for our Prosperity

SDGs determined targeting to ensure that all human beings can enjoy prosperous and fulfilling lives and that economic, social and technological progress occurs in harmony with nature.

See Auditor here is an ide for our Peace

SDGs determined targeting to foster peaceful, justice and inclusive societies which are free from fear and violence. There can be no sustainable development without peace and no peace without sustainable development.

See Auditor here is an ide for our Partnership

SDGs determined targeting to mobilize the means required to implement this Agenda through a revitalized Global Partnership for Sustainable Development, based on a spirit of strengthened global solidarity, focused in particular on the needs of the poorest and most vulnerable and with the participation of all countries, all stakeholders and all people.

SDGist $\quad$ : Auditor... look at this framework as what 5Ps are (OECD, 2016). 


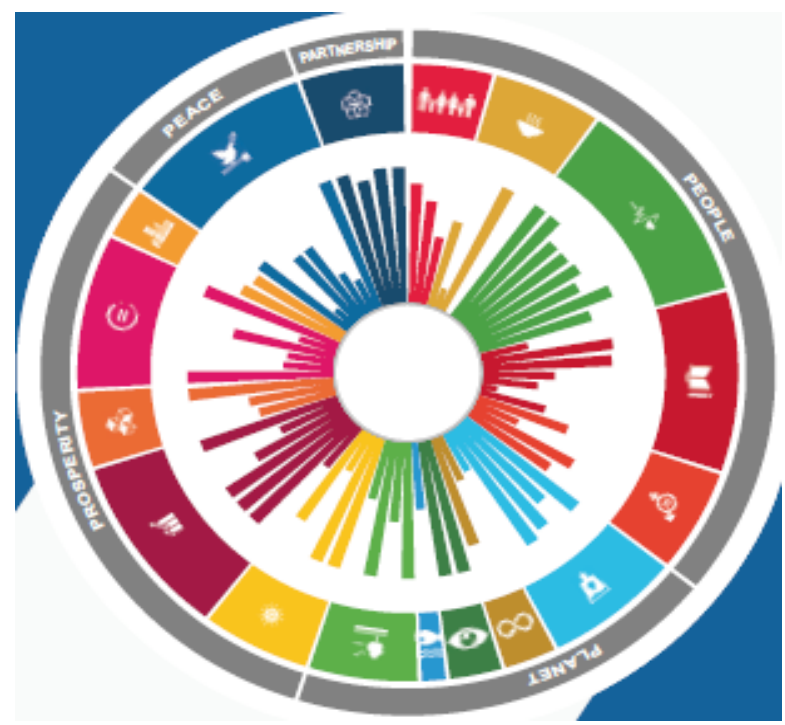

Auditor $\quad$ : Luar biasa, ya SDGist ... (awesome, ya SDGist ...)

Auditor $\quad$ : Lho ... here is becoming 5Ps, SDGist. It was 3Ps as People, Planet and Profit, what it has been declared by Elkington.

SDGist $\quad$ : Bedo iki ... (Here is different), in the sense of People, Planet, Prosperity, Peace and Partnership, as 5Ps

SDGist $\quad$ : But, Auditor ... it needs much efforts to achive them ... Jer Basuki Mawa Beya.

Auditor : Opo iku Romo? (What is that, Romo?)

SDGist $\quad$ : Ngene ... iku ngono (bringing a meaning) ... No Victory Without A Fight, or No Free Lunch, or No Prosperity Without an Effort.

As proclaimed by the UN, the 5Ps have to be interlinkaged and integrated. No single agenda is inseperable (United Nations, 2015). SDGs present it is a rhetorical tool that every government official as the UN Member and international aid workers have to pay much attention to hold accountable the appropriate actors in the agenda. The state member, eg, Indonesia in the SDG process needs to go back to the its national plan and SDGs agenda. State what the goals are for. Reduce the number of goals, targets, and indicators, focusing on those areas that should be prioritized on the international agenda as it is SDGs. Set ambitious targets based on feasible rates of progress. Define key terms. Stop acting like this is a utopian document. If it remains so, it will be as meaningless as the many international proclamations which have preceded it. That is the key to go forward reaching the goals.

Auditor $\quad$ : SDGist, really deep meanings ... SDGist. Yes ... I agree with that too SDGist. So far when I trace, SDGist, every nation has their own agenda, SDGist. They do not have a linkage to the international agenda. ... Parah itu SDGist ... (It is ridiculous, SDGist)

Auditor $\quad$ : SDGist, to some extents, the leader of any state/ nation must have international views. He or she cannot think by him/ her self, they must linkage with international agenda, SDGist.

SDGist : Yes it is right, Auditor. 


\section{Method of Exploration}

The paper is postmodernism in nature. It explores some understandings of the phenomena of SDGs by using an imaginary dialogue. Postmodernism is used for bringing up ideas in minds based on observed and unobserved phenomena (Sukoharsono, 2016). Two professionals are made up to explore their minds imaginarily. They are with the names of SDGist and Auditor. SDGist is representing a scholar who has good knowledge on SDGs, whereas Auditor is as a professional who has a competence in financial and non-financial audit.

SDGist : Auditor ... The idea using postmodernism is because it gives much choices of the ways we do to write and explore our minds.

Auditor $\quad$ : Yes, you are right, SDGist, for me, postmodernism is unstructured mode of writing. That is why, an imaginary dialogue is one of objectives to explore some strategies that could be understood by readers.

SDGist : Some references are collected as sources, and experiences are also as sources of knowledge.

Auditor : Definitely this is a research too.

SDGist : Why it is not. Yes, it is.

\section{The ICSP on SDGs Implementation: Socializing the Sustainability Report}

The ICSP, the Institute of Certified Sustainability Practitioners, is an association that promotes Sustainability Practitioners who granted a certificate of Sustainability Reporting Specialist and/ or Sustainability Reporting Assuror to share and exchange the knowledge. The ICSP is initiated by NCSR (National Center for Sustainability Reporting) as an official representative of GRI in the ASEAN Region, in particular Indonesia, Malaysia, Singapore and Philippines. The NCSR was founded in 2005. Then in 2015, it established the ICSP and centered in Jakarta, Indonesia.

Auditor : SDGist, what is the main objective of the ICSP?

SDGist : As far as I concern, before answering the main objective of the ICSP, the main VISION of the ICSP is "to be the leading professional association in fostering knowledge and practices of sustainability and assurance reports as well as other related fields, oriented on ethic, social, economic and environmental accountability."

To achieve this vision ICSP, its MISSIONS are as follows :

1. Maintaining the integrity, commitment and competence of members

2. Fostering knowledge of sustainability reporting practices, accounting sustainability, and assurance reports, and

3. Actively participating in the enforcement of good governance, socially and environmentally responsible in national, regional and international perspectives.

The objectives of the Institute are

1. To raise professional potentials of Indonesians and regionals, and certified sustainability practitioners to drive national and regional developments on sustainability

2. To foster and develop the potential of certified sustainability professionals to contribute to the development of the nation and regions 
3. To serve as a communication forum on sustainability that bridge Members with various backgrounds (i.e., academicians, private and public institutions) so that they could synergy in harmony

Auditor : SDGist, could I join a member of it?

SDGist : Of course, you could. But, you must have a certificate of Sustainability Reporting Specialist and/ or Sustainability Reporting Assuror by passing its exams of the ICSP. Currently it has members of more than 1,500 professionals across of ASEAN.

Auditor : Why is Sustainability Report important?

SDGist $\quad$ : Well ... Auditor, let me starts by defining what is sustainability.

Sustainability is in brief, the capacity to endure. For human sustainability, it is a long term of maintenance of well-being, which has social, economic, and environmental dimensions. In ecology, sustainability describes how biological systems remain diverse and productive over time.

Auditor ... whereas Sustainability Reporting (SR) is organization's practice of reporting publicly on its economic, social and environmental impacts and hence its contributions - negative and positive - towards the goals of sustainable development.

Auditor $\quad$ : thus... its spirit is the same as financial report.

SDGist $\quad:$ Yes ... you are right ... Please see my slides for more details.

SDGist : For Transparency, the SR creates a common language for organizations and stakeholders with which economic, social and environmental impacts of organizations are communicated and understood. SR (with the standards of e.g., GRI) is designed to enhance the global comparability and the quality of information on these impacts, thereby enabling transparency of organizations.

For Accountability, the SR creates the obligation of organizations to account its activities and accept responsibility and to disclose the results concerning economic, social and environmental impacts of organizations.

For Anti-Corruption, the SR shall account the following (Global Reporting Standards, 2016): 


\section{Topic-specific disclosures}

\section{Disclosure 205-1 \\ Operations assessed for risks related to corruption}

Reporting requirements
$\begin{array}{ll}\text { Disclosure } & \text { The reporting organization shall report the following information: } \\ \text { a. Total number and percentage of operations assessed for risks related to corruption. } \\ \text { b. Significant risks related to corruption identified through the risk assessment. }\end{array}$

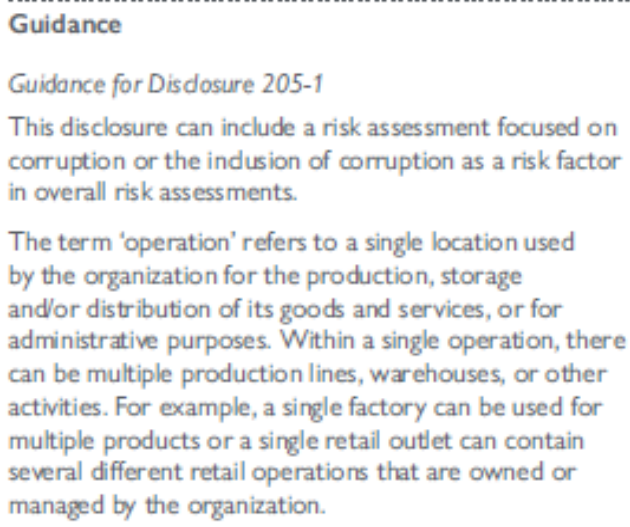

This disclosure can include a risk assessment focused on corruption or the indusion of corruption as a risk factor in overall risk assessments.

The term 'operation' refers to a single location used by the organization for the production, storage and/or distribution of its goods and services, or for administrative purposes. Within a single operation, there can be multiple production lines, warehouses, or other activities. For example, a single factory can be used for multiple products or a single retail outlet can contain several different retail operations that are owned or managed by the organization.

\section{Background}

This disclosure measures the extent of the risk assessment's implementation across an organization. Risk assessments can help to assess the potential for incidents of corruption within and related to the organization, and help the organization to design policies and procedures to combat corruption

\section{Disclosure 205-3}

\section{Confirmed incidents of corruption and actions taken}

\section{Guidance}

Guidance for Disdosure 205-3

For stakeholders, there is an interest in both the occurrence of incidents and an organization's response to the incidents. Public legal cases regarding comuption can include current public investigations, prosecutions, or dosed cases. 


\section{Disclosure 205-2 \\ Communication and training about anti-corruption policies and procedures}



Reporting recommendations

2.1 When compiling the information specified in Disclosure 205-2, the reporting organization should:

2.1.1 draw from the information used for Disclosure 405-1 in GRI 405: Diversity and Equal Opportunity to identify:

2.1.1.1 the governance bodies that exist within the organization, such as the board of directors, maragement committee, or similar body for non-corporate organizations;

2.1.1.2 the total number of individuals and/or employees who comprise these governance bodies;

2.1.1.3 the total number of employees in each employee category, excluding governance body members;

2.1.2 estimate the total number of business partners.

Guidance

Background

Communication and training build the internal and external awareness and the necessary capacity to combat corruption.

\section{E-Government Leveraging the Transparency, Accountability and Anti-Corruption}

e-Government is now almost the common word dealing with a model to run governmental management. Principly, e-Government is the use of information and communication technologies (ICTs) as we are now in the era of Industrial Revolution 4.0 to improve the activities of public sector organisations. In practice, e-government is the use of internet enabling applications to run the government activitis, or interacting between government and outside groups to be transparant, accountable and declaring anticorruption.

SDGist : Auditor, look at this, I would like to inform you some efforts have been reported it to the public. This is a report prepared by United Nations.

Auditor, recently on 3 August 2016 - A new United Nations report has found that egovernment is an effective tool for facilitating integrated policies and public service by promoting accountable and transparent institutions, such as through open data and 
participatory decision-making, and therefore it has the potential to help support the implementation of the 2030 Agenda for Sustainable Development and its 17 SDGs. This is a good report to show that e-government could support leveraging the success of SDGs (United Nations, 2016).

ICT is to truly transform the public sector into an instrument of sustainable development, efficiency in service delivery is possible to making social equity and ensuring that all people can access quality services. This is what ICT could be used to transform people better lives.

The report 2016 UN E-Government Survey provide a map of how e-government is implemented and used. Interestingly the report is produced every two years by the UN Department of Economic and Social Affairs, and is the only global report that assesses the e-government development status of all 193 Member States of the UN.

In the latest edition, the report found that countries in all regions are increasingly utilizing new information and communication technologies to deliver services and engage people in decision-making processes. At the same time, the report also uncovered that substantial regional disparities and a growing divide continues to persist. Furthermore, lack of access to technology, poverty and inequality prevent people from fully taking advantage of the potential of ICTs and e-government for sustainable development.

While Europe continued to lead on e-government, followed by the Americas, Asia and Oceania, Africa lagged furthest behind.

Below is the result of the survey on top e-government performers.

\begin{tabular}{|c|l|}
\hline NO & \multicolumn{1}{|c|}{ TOP E-GOVERNMENT PERFORMERS } \\
\hline $\mathbf{1}$ & United Kingdom \\
\hline $\mathbf{2}$ & Australia \\
\hline $\mathbf{3}$ & Republic of Korea \\
\hline $\mathbf{4}$ & Singapore \\
\hline $\mathbf{5}$ & Finland \\
\hline $\mathbf{6}$ & Sweden \\
\hline $\mathbf{7}$ & Netherlands \\
\hline $\mathbf{8}$ & New Zealand \\
\hline $\mathbf{9}$ & Denmark \\
\hline $\mathbf{1 0}$ & France \\
\hline $\mathbf{1 1}$ & \\
\hline $\mathbf{1 2}$ & United States of America \\
\hline
\end{tabular}

SDGist : Auditor, please see the table of the Top E-Government implemented. Globally, the United Kingdom, Australia and Republic of Korea, occupied the top three positions in providing government services and information through the Internet. The United States ranked twelfth overall.

Auditor : :SDGist, when we see the global phenomena, it seems USA is the top, but in fact based on the UN survey, they are far. See South Korea, they beat Singapore, SDGist.

SDGist : Interestingly, the top e-government performers listed have good average in their social prosperity. See Auditor, all the countries above listed have relatively better in education systems.

SDGist : See now at the regional table: 


\begin{tabular}{|c|c|c|}
\hline NO & \multicolumn{2}{|c|}{$\begin{array}{l}\text { REGIONAL TOP E-GOVERNMENT } \\
\text { PERFORMERS }\end{array}$} \\
\hline \multirow{2}{*}{1} & \multirow{2}{*}{ AFRICA } & Mauritius \\
\hline & & Tunisia \\
\hline \multirow{2}{*}{2} & \multirow{2}{*}{ AMERICA } & United States of America \\
\hline & & Canada \\
\hline \multirow{2}{*}{3} & \multirow{2}{*}{ ASIA } & Republic of Korea \\
\hline & & Singapore \\
\hline \multirow{2}{*}{4} & \multirow{2}{*}{ EUROPE } & United Kingdom \\
\hline & & Finland \\
\hline \multirow{2}{*}{5} & \multirow{2}{*}{ OCEANIA } & Australia \\
\hline & & New Zealand \\
\hline
\end{tabular}

SDGist

: Auditor, when we see the regional table, we could find that in Africa, the small island nation of Mauritius was the top performer. It ranked 58th worldwide.

SDGist : Auditor, please do not be confused with the table. On the E-Government Development Index (EGDI) African countries averaged 0.2882, while European countries, averaged almost 2.5 times higher, at 0.7241 . This means that the table does not reflect it to compare among the region. As reported, the EGDI measures a country's use of information and communications technologies to deliver public services and governmental management. The index is based on the indicators of three dimensions: the scope and quality of online services, the status of telecommunication infrastructure, and the existing human capacity.

Auditor $\quad$ : SDGist... I agree to say that table is used by its context.

SDGist $\quad$ : For now, I will show you how is about in Europe. Based on the UN report of 2016, Europe provides 10 times more services to the poor, persons with disabilities and older persons than Africa and Oceania.

Based on the imaginary dialogue between SDGist and Auditor, the implementation of e-government could provide positive impact on the success of SDGs. SDGs have potential to be implemented using ICT. To realize the full potential impact of e-government and ITC in general for SDGs, the report finds that the level of e-government could ensure the level of access and availability the government to response the need for SDGs' success and make public institutions more accountable and more responsive to people's needs. It means the ICT is bringing an impact to a rapid response to the implementation of SDGs. The survey also concludes that it is essential to ensure that the overarching objective of poverty eradication and "Leaving No One Behind", a key principle of the 2030 Agenda, are at the core of efforts to mobilize ICT to realize the transformation the 2030 Agenda demands (United Nations, 2016)

\section{Promoting More Investmet to the Target of 16.4-16.6}

In any cases, investment is a vital role in making things succeeded. Spending more money is necessary to achieve the goals of a country development. SDGist is bringing an imagination to discuss about more investment to the implementation of the Goal 16.4 to 16.6 
Auditor : SDGist, do you agree promoting more investment leveraging the success of the Goal 16.4 to 16.6 ?

SDGist : Auditor, my answer is that money is every thing. No money will be no game. No money will be no remunaration.

Auditor : SDGist, thus money is 'God', then. Wkk wkk wkk ....

SDGist : Well Auditor, to run the SDGs, they need money. For example, to eradicate corruptions and briberies, a country must spend their money on regular risk assessment, training of anti-corruption and updating SOP and providing more public facilities. This means it needs money, Auditor.

Auditor : With more investment, transparency, accountability and anti-corruption could be managed and controlled.

\section{Fitting Policies Nationally and Internationally Relevant To the Target of 16.4-16.6}

Imagining if the national policies are not synchronous to the SDGs, it will lead to the unsuccessful SDGs. National policies must fit to the SDGs.

SDGist : Auditor, I am now thinking how any policies must fit to the SDGs. Policy is important to drive where developments must go.

SDGist $\quad:$... policy is a system, Auditor. With no policy, any government will suffer.

Auditor : SDGist, I agree with the idea fitting national policies to the SDGs spirit. To achieve the success of the target 16.4-16.6 is needed a linkage of the national policy and international organizations.

Auditor : National policy of the use of the GRI Standards is important to be a linkage to the international policy. This will promote the transparency and accountability of the organizations.

\section{Supporting Inclusive Growth and Well-Being}

The spirit of SDGs is to leave no one behind. This leads to an effect that Goal 16.4-16.6 are bringing all to go forward for the people prosperity. Referring to the OECD framework to measure 'well-being', they focus on people rather than the economic system.

SDGist : Auditor, well-being is for people.

People must be well mentally and physically. SDGs promote all people have their right to live well. Any nation should protect their people should live in good condition by enviironmentally and socially.

Auditor $\quad$ : Transparency and accountability are critical for inclusive growth and well-being. This means that all institutions must promote all people within it to actively contribute to their prosperity, no one left behind.

\section{Ensuring the 5Ps' Sustainability}

Sustaining people, planet and profit is no choice. We live with the 5Ps here. Successful implementation of the SDGs will require striking a balance between socio-economic progress with anticorruption, sustaining the planet's resources and ecosystems, technology, and spirituality.

SDGist : : Auditor, here is the ICSP driving an example

Auditor : How is that? 
SDGist : Example of the ICSP is the way to work with. The ICSP works with its members, partner countries and other stakeholders to ensure sound model of SR on environmental management that supports the sustained achievement of economic development and prosperity, while delivering human security and resilience.

Auditor : (with emphasis ...) The 5Ps here are People, Planet, Profit, Phenotechnology and Prophet (Spiritual values).

\section{Promoting Partnerships}

Working together across the world is a spirit of protecting our lives. No war is a must. To implement the goal 16.4-16.6 and its targets, governments all over the world, international and non-governmental organisations, the private sector and civil society will need to team up. Working together they can unlock the necessary financial resources, share technologies, transparency, accountability and create national capacities.

SDGist : Auditor, here is the ICSP driving an example

Auditor $\quad$ : We need an example from any experience institution.

SDGist : The ICSP provides a platform for dialogue and exchange. Together with its members from different backgrounds and institutions it supports the Global Partnership (ASEAN Countries) for Effective Development Co-operation, which brings all stakeholders to a table to discuss development issues on an equal footing.

Auditor : With partnership, we could share values combatting trans-global corruptions. We could have hands in hands tracing trans-global corruptions with the partner organization and combatting them together.

SDGist : With partnership, we could also have more resources and expanded stakeholders regionally and internationally in the transparency and accountability of information.

\section{Strengthening Data Availability and Capacity}

Turning the target of the Goal 16.4-16.6 into reality will require robust data to capture progress and evidence to inform decision making.

SDGist : Auditor, data are the foundation of information. If no data, there will be no information.

Auditor $\quad$ : OECD has emphasized on strengthening data availability and capacity. The OECD is helping countries to track progress in areas such as trust, combating all forms of organized crimes, illicit financial flows, income and consumption inequality, and job quality. It supports countries in developing and using environmental and green growth indicators and in achieving environment-economy integration over time (OECD, 2016).

Auditor : We cannot promote transparency and accountability, if the data are not available.

SDGist : Now we are in Industrial Revolution 4.0, this means data are essential getting ready.

Auditor : Combatting anticorruption means we are based on data.

SDGist : Through Sustainability Report, data will be available there, then transparency and accountability could be traced from it. 


\section{Facilitating Follow Up and Review}

In promoting transparency, accountability and anticorruption, follow up and review are the essential agenda to strengthen its current issues. Of course, inclusive follow up and review mechanisms will be essential to incentivise action and learning around the 2030 Agenda.

SDGist $\quad$ : Auditor, we can get more benefits of follow up and reviews

Auditor $\quad$ : I can get it ... follow up and review are to strengthen its issues and importance

SDGist : In our experiences, reviews are to know where to intervene to make effective and sustainable, continuous improvements.

Auditor : For accountability purposes, program review enables an institution to know and to understand the distinctive strengths, accomplishments, needs, and future plans of the program. In turn, this enables the institution to offer support, identify areas of common interest in the phenomena, to link individual members of staff or entire institution with relevant resources on- and off-boundaries, and to meet identified resource needs.

Auditor : (with emphasis of his 'hard' voice) overall of follow up and review are necessary in promoting transparency, accountability and anticorruption agenda.

\section{Epilogue}

SDGist $\quad$ : Auditor ... we are now coming to a conclusion.

Auditor $\quad$ :Yes, I think we have a spirit in understanding more about SDGs in particular targeting the Goal of $16.4-16.6$.

SDGist : Auditor ... when we are back to the objective of the paper, we could conclude that there are 9 strategies to improve the sustainability in promoting transparency, accountability and anticorruption.

Auditor $\quad:$ (With calm ... and softly ...) These are important to be remembered and implemented, which are the ICSP on SDGs Implementation: Socializing the Sustainability Reporting, implementing of e-government, promoting more investment, fitting policies nationally and internationally relevant to the goal 16.4 to 16.6 , supporting inclusive growth and well being, ensuring the 5Ps' sustainability, promoting partnerships, strengthening data availability and capacity, and facilitating follow up and review.

SDGist $\quad$ : You are right, Auditor ... Those are our dialogue results. See you around ... 


\section{REFERENCES}

Global Reporting Initiative. 2016. Consolidated Set of GRI Sustainability Reporting Standards 2016.

ICSU, ISSC. 2015. Review of the Sustainable Development Goals: The Science Perspective. Paris: International Council for Science (ICSU).

OECD. 2016. Measuring Distance To the SDGs Targets: A Pilot Assessment of Where OECD Countries Stand.

Sukoharsono, Eko Ganis. 2007. Green Accounting in Indonesia: Accountability and Environmental Issues. The International Journal of Accounting and Business Society. Vol.15. No 1. August. Pp.23-66.

Sukoharsono, Eko Ganis. 2016. An Imaginary Dialogue on Leveraging to Achieve the Success of SDGs. The 1st Sustainability Practitioners Convention, Malang, 24 November 2016

Sukoharsono, Eko Ganis. 2017. Sustainability Report and Creating Shared Value: Sustaining a Business of Urea Fertilizer Manufacture in the Case of Pupuk Kaltim Indonesia. SIBR-RDINRRU 2017 (Sydney) Conference on Interdisciplinary Business and Economics Research, 15th - 16th April, Sydney, Australia

Sukoharsono, Eko Ganis. 2017. Dialog Imajiner Luca Pacioli dan Luca Serius: Green Accounting di Indonesia (Imaginary Dialogue Between Luca Pacioli and Luca Serious: Green Accounting in Indonesia). National Seminar on Green Accounting In Indonesia, Why and How. Universitas Mulawarman. 25 September 2017.

United Nations. 2015. Transforming Our World: The 2030 Agenda for Sustainable Development United Nations. 2016. UN E-Government Survey 2016. 